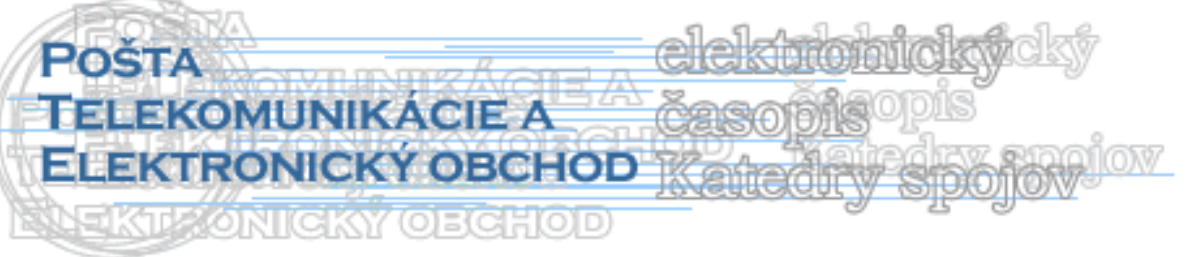

\title{
ODBYTOVÉ STRATÉGIE ZAMERANÉ NA MARKETINGOVÚ KOMUNIKÁCIU
}

\author{
Viera Frianová ${ }^{1}$
}

\section{Úvod}

Moderný marketingový prístup znamená, že firma systematicky sleduje potreby, priania, vnímanie, preferencie a spokojnost' zákazníka. Orientácia na zákazníka nie je možná bez komunikácie s ním. Tak, ako sa mení pohl'ad na vývoj pri marketingovom riadení, v posledných rokoch nadobudla výnimočné rozmery aj komunikácia. Spoločnost' nazývaná „informačná spoločnost“" využíva mnoho rôznych foriem komunikácie. Zmenili sa požiadavky zákazníka (výrazne sa diferencujú), kvantitatívne ale predovšetkým kvalitatívne sa zmenil spôsob komunikácie, skoršie najpoužívanejší spôsob osobného kontaktu je stále viac nahrádzaný kontaktom prostredníctvom rôznych technických prostriedkov. Celkový význam komunikácie $\mathrm{v}$ marketingu prispel $\mathrm{k}$ stále častejšie používanému spojeniu „marketingu“ a „komunikácie“ do tzv. marketingovej komunikácie. Jej rastúci význam pre úspech firmy spolu so skutočnost'ou, že v súčasnosti je jedným z najviditel'nejších a najdiskutovanejších nástrojov marketingového mixu zdôrazňuje potrebu venovat' sa tejto problematike ako zhl'adiska teórie (poznanie vlastných nástrojov marketingovej komunikácie), tak z pohl'adu hl'adania spôsobov jej vhodného uplatňovania v činnosti firiem.

\section{Stratégie prvkov marketingovej komunikácie}

Clemente, N. M. (2004) označuje aktivity využívané na prenos informácie o výrobku, ktorý má byt' predstavený pre spojenie s potenciálnymi zákazníkmi a s ostatnou verejnost'ou ako marketingový komunikačný mix (marketing communications mix). Autor d’alej uvádza, že marketingové komunikačné mixy (tiež nazývané ako propagačný mix) pozostávajú zo štyroch hlavných nástrojov: reklamy, podpory predaja, public relations a osobného predaja. Všeobecné rozhodnutie o marketingovej komunikácii zahŕňa rozhodovanie o tom, čo povedat', komu to povedat' a ako to povedat'. Tieto rozhodnutia obsahujú tzv. komunikačnú stratégiu spoločnosti. Vývoj tejto stratégie zahŕňa zistenie ciel'a poslucháčov, divákov, čitatel'ov atd'. a ich charakteristík, stanovenie komunikačných ciel'ov (napr. pripravenie spotrebitel'a na to, aby si produkt uvedomoval, aby sa mu páčil, alebo si vytvoril pre daný produkt preferencie), rozhodnutia o komunikačných kanáloch, stanovenie rozpočtu na komunikáciu a rozhodovanie o tom, ako monitorovat' účinnost' komunikácie a spätnú väzbu so spotrebitel'om.

Propagačný mix (promotion mix) Clemente, N. M. (2004) vymedzuje ako kombináciu propagačných (promočných) techník používaných na komunikáciu informácií o produkte alebo službe smerom k ciel'ovému trhu. Propagačný mix na delí do dvoch kategórií na:

\footnotetext{
${ }^{1}$ Ing. Viera Frianová, Katedra manažmentu, Akadémia Ozbrojených síl gen. M. R. Štefánika, Liptovský Mikuláš tel. 0960423525

e-mail: frianova@aoslm.sk
} 
priamu propagáciu (direct promotion) - zahŕňa osobný predaj spotrebitel'om (bud' z očí do očí alebo vd'aka technikám ako je telemarketing), nepriamu propagáciu (indirect promotion) obsahuje použitie reklamy, publicity a propagácie predaja t. j. taktiky komunikácie informácie o produkte prostredníctvom neosobných kanálov. Tvorba stratégie propagačného mixu je založená na identifikácii ciel'ového trhu, na ktorý má byt' nasmerovaná komunikácia a stanovení ciel'ov komunikácie (napr. rozhodnutie, aké informácie je potrebné poskytnút', ako sú určené a ako sa menia úrovne spotrebitel'ského povedomia a postoje o produkte). V rámci propagácie sa rozlišuje: propagácia imidž (image advertising), propagácia medzi spotrebitel'mi (consumer promotion), propagácia na predajnom mieste - P-O-P (point-ofpurchase advertising), propagácia obnovenia predplatného (renewal promotion), propagácia pomocou adresára (directory advertising), propagácia pre získanie člena členom (member-getmember promotion), propagácia pred tlačou (pre-print advertisement), propagácia verejných služieb (public service advertising), propagačné materiály (collateral materiale), propagačné oceňovanie - tvorba cien (promotion pricing), propagačné skonto - odmena (promotional allowance).

Podl’a Š́́bla, D. (2002) možno komunikačný mix (communication mix) definovat' ako: „súhrn prvkov komunikácie firmy s okolím a spôsob ich kombinácie. Jeho súčast'ou sú najmä reklama, podpora predaja, osobný predaj, vzt'ahy s verejnost'ou, vel'trhy a výstavy. Prvky marketingu sa pri vytváraní komunikačnej stratégie kombinujú, a to podla skúseností, znalostí a zodpovednosti manažmentu firiem. Tento proces l'ahšie prebieha v prostredí domáceho trhu, pri jeho aplikácii v prostredí medzinárodných trhov treba brat' do úvahy rôzne bariéry, napr. kultúrnu bariéru jednotlivých trhov, bariéru rôznych miest vzniku posolstva a jeho použitia a pod.“

Je potrebné uviest', že budúce smerovanie marketingu v 3. tisícročí bude významne ovplyvnené aj procesom globalizácie, ktorý sa prejaví najmä v snahe štandardizovat' komunikačnú politiku firiem (t. j. medzinárodne zjednotit' komunikačné nástroje ako sú klasická reklama, podpora predaja a public relations). .

\section{1 Stratégia reklamy}

V súčasnosti je reklama považovaná za dôležitý ak nie najdôležitejší nástroj hromadného predaja. Hromadný predaj umožňuje širokú distribúciu. Nie je taký flexibilný ako osobný predaj, ale pôsobí naraz na vel'ký počet potenciálnych zákazníkov. Marketingoví manažéri musia rozhodnút': kto je ich ciel'ové „publikum“, aký druh reklamy použit', ako pôsobit' na zákazníkov (prostredníctvom akých typov médií), čo im povedat' (razantnost' reklamy) a kto vykoná danú prácu (vlastné oddelenie reklamy, alebo externé agentúry). Firmám pri realizácii reklamy často pomáhajú reklamné agentúry, ktoré sú považované za odborníkov $\mathrm{v}$ oblasti plánovania a realizácie hromadného predaja, sú nezávislé od zadávatel'ov, na problém sa pozerajú zvonku. Ked’že majú bohaté skúsenosti z práce pre mnohých zákazníkov, ich práca je často efektívnejšia ako práca vlastného oddelenia firmy (Horñák, 1997).

Reklama patrí bezpochyby k najstarším a najrozšírenejším nástrojom ovplyvňovania kupujúcich, stala sa neodmyslitel'nou súčast'ou nášho života. Aj napriek tomu, že sa v praxi bežne využíva, neexistuje jej jednotná definícia. Reklamou možno označit' každú platenú formu nepersonálnej prezentácie a podpory myšlienok, tovaru alebo služieb, ktorú vykonáva identifikovatel'ný zadávatel'. Podl'a Zákona NR č. 220/96 Zb. o reklame ,je reklama verejná informácia uskutočňovaná prostredníctvom nosičov informácií, ktorej účelom je informovat' spotrebitel'a o produktoch, presviedčat' a získat' ho na ich užívanie alebo inak ovplyvňovat' jeho rozhodovanie pri výbere produktov“" (Fekete, 1996).

Definícia Zymana, S. (2004) hovorí, že: „reklama je úplne všetko, skrátka všetko čo robíte, hovorí niečo o vašej značke zákazníkom a potenciálnym zákazníkom. To všetko 
ovplyvňuje spôsob, akým sa l'udia pozerajú na vaše produkty, to všetko má vplyv na to, či niekto bude kupovat' to, čo ponúkate“.

Je potrebné zdôraznit', že stratégia reklamy musí byt' jasne definovaná, t. j. musí dávat' jasnú predstavu o tom, čo ňou chce firma dosiahnut'. Presné definovanie ciel'ov reklamy znamená určenie ciel'ovej skupiny, komunikačného ciel'a; zmeny, ktorú chce firma dosiahnut' a určenie časového horizontu, kedy má byt' ciel' dosiahnutý (Kotler, 1992). Predpokladom dosiahnutia plánovaného efektu reklamy je správny výber reklamnej metódy, zohl'adňujúci náklady, výhody a nevýhody tej ktorej metódy.

Podl'a zamerania možno rozlíšit' reklamu všeobecnú (označovanú aj ako reklamu výrobku), reklamu značky, reklamu inštitúcie a kooperačnú reklamu (Grančičová, 1999). Na základe poslania možno rozlíšit' reklamu, ktorá má informovat'; reklamu, ktorá má presvedčit'; reklamu, ktorá má pripomenút' a reklamu, ktorá má potvrdit' správnost' nákupného rozhodnutia (Kotler, 2003). Z hl'adiska objektu, na ktorý je reklama zameraná možno rozlíšit' reklamu zameranú na spotrebitel'a a reklamu zameranú na obchod (Hingston, 2002). Medzi nové druhy reklamy patria: inforeklama (dlhé televízne reklamy trvajúce až do 3 minút); reklamy na banneroch (reklamných prúžkoch na webových stránkach Internetu, obsahujúcich názov inzerujúcej firmy, ktorá si za ich umiestnenie na danú stránku musí zaplatit'); reklamy i-Candy (jedná sa opät’ o reklamu na Internete, ktorá sprostredkúva reklamnú správu pomocou animácie a hier; Dwek, R. daný pojem vysvetl'uje ako "úsmevné a niekedy aj trochu drzé ikonky a bannery, ktoré sa rozbalia, ked' sa na ne klikne, spustia sa akoby nová webová stránka a na nej sa spustí zaujímavá grafika a pôsobivá hudba; vložená reklama na Internete (tzv. „interstitial“ alebo „intermercial“ je dotieravá animovaná reklama, obvykle vo vel'kosti celej obrazovky, ktorá sa objavuje v obsahu jednotlivých webových stránok a funguje podobne ako televízny spot); reklama „subvert“ (je prístupná prostredníctvom celosvetovej siete Internet, ak užívatel' na banner klikne, získa 20 sekúnd obrázkov a zvukov o propagovanej značke, a potom sa automaticky vráti na pôvodnú webovú stránku); šetriče obrazovky (každý počítač sa tak stáva potenciálnym miestom pre reklamu); úzko zamerané televízne vysielanie (publikum sa člení na celý rad menších záujmových podskupín, ktoré sledujú svoje relácie, kanály, programy a pod.) (Smith, 2000). S ohl'adom na fázy životného cyklu produktu môžeme rozlíšit' reklamu zavádzaciu, udržiavaciu a pripomínaciu (Frianová, 2000).

Aj ked' si reklamu obvykle kupujeme podobne ako ktorýkol'vek produkt, na rozdiel od tradičných výrobkov má niekol'ko zvláštností: reklama je dlhodobou investíciou, napriek tomu sa náklady na ňu nedajú postupne odpisovat; kvalita reklamy sa nedá objektívne určit'; nikto nevie presne vypočítat', kol'ko reklamy si treba „kúpit"“, aby to stačilo. Reklama je vel'mi expresívna, umožňuje firme propagovat' produkt $v$ dramatickej forme pomocou umeleckého stvárnenia, písma, zvuku a farby. Je to oblast', ktorá dáva príležitost' rôznym profesiám, najcennejšou je však kreativita a umenie komunikácie. Úroveň reklamy hovorí o l'udskej fantázii, ume a stratégii. Dokáže odmeňovat', ale rovnako nel'útostne poukáže na chyby, ktoré sa stali (Vávra, 1998).

\section{2 Stratégia podpory predaja}

Americká marketingová asociácia definuje podporu predaja (sales promotion) ako mediálny a nemediálny tlak použitý na vopred stanovenú, obmedzenú dobu na úrovni spotrebitel'a, maloobchodníka či vel'koobchodníka za účelom stimulácie prvého nákupu, zvýšenia spotrebitel'ského dopytu či zlepšenia dostupnosti výrobku. Podporu predaja možno označit' aj za diverzifikovanú formu masovej komunikácie, ktorej podstatou je motivovat' zákazníkov ku kúpe produktu v určitom čase (Perreault, 1990).

Ciel'om podpory predaja je narušit' zvyky spotrebitel'ov pri nakupovaní a dopyte po tovaroch a službách, teda presvedčit' ich natol'ko, aby si daný produkt hned' kúpili alebo 
objednali. Využíva slabost' zákazníka voči (aspoň na prvý pohl'ad) výhodnej ponuke, ako je napr. znížená cena, možnost' dostat' darček či d'alší kus zadarmo a pod. Podpora predaja nemôže byt' permanentnou akciou, ktorá sa donekonečna bez obmeny opakuje, pretože či chceme alebo nie, po čase sa „ošúcha“ a prestane byt' pre zákazníka zaujímavou. Využívame ju hlavne $\mathrm{v}$ dvoch etapách životného cyklu produktu, a to pri jeho zavádzaní na trh a po dosiahnutí nasýtenia trhu (Vávra, 1998). Výhodou podpory predaja je vysoká účinnost' a efektívnost' vynaložených prostriedkov. Náklady na podporu predaja sú všeobecne nižšie, ako náklady na reklamnú kampaň a dajú sa dobre regulovat' (napr. tým, že určíme počet výhercov v sút’aži).

Rozlišujeme nástroje podpory predaja zamerané na spotrebitel'a čiže spotrebitel'skú promotion, ktorá využiva vzorky, kupóny, rabaty, cenové zl’avy, prémie, sút’aže, známky, prehliadky, výstavy a iné. Ďalej poznáme nástroje motivujúce subjekty distribučných kanálov, predovšetkým vel'ko a maloobchodníkov, tvoriace obchodnú promotion. Sem patria príplatky, odmeny, tovar poskytovaný zdarma, spoločná reklama, sút’aže dealerov a iné. Tretia skupina nástrojov podpory predaja sa orientuje na obchodný personál - bonusy, sút'aže, stretnutia predávajúcich, organizovanie výchovno-vzdelávacích kurzov, seminárov, tréningov. Aj ked' ich niektorí autori zarad'ujú do obchodnej promotion, zastávam názor, že je vhodnejšie ich samostatné vyčlenenie. Uvedené nástroje sa obyčajne využívajú v kombinácii spolu $\mathrm{s}$ reklamou a osobným predajom (Kotler, 1992).

Podl'a Hingstona, P. (2002) možno na podporu predaja využit' nasledovné propagačné techniky: pracovné obedy, sút’ǎe alebo vecné lotérie, kupóny, poukážky a zákaznícke karty, módne prehliadky, bezplatné darčeky, bezplatné otestovanie, predvádzanie v obchode, spoločné podniky, rozosielanie propagačného materiálu, dni otvorených dverí, vzorky, video a CD.

Kotler, P. (2003) uvádza, že akcie na podporu predaja prinášajú rýchlejšie a lepšie meratel'né výsledky, odrážajúce sa vo výške tržieb, ako reklama. Dnešný pomer medzi využívaním reklamy a podpory predaja sa odhaduje na 30:70, zatial', čo kedysi to bolo opačne. Väčšie využívanie akcií na podporu predaja odráža skutočnost', že podniky dnes kladú väčší dôraz na krátkodobé predajné výsledky ako na dlhodobé vytváranie značiek. Ide skôr o návrat k tzv. transakčnému marketingu ako o súčast' vzt'ahového marketingu.

Aj ked' podpora predaja má všeobecne krátkodobú, taktickú, na okamžitý efekt zameranú podstatu, všetky jej akcie by mali byt' súčast'ou väčšej a dlhodobejšej stratégie. Aj ked' je podpora predaja definovaná ako realizácia krátkodobých podporných aktivít, v súčasnosti sa čoraz častejšie zdôrazňuje, že jej súčast'ou sú aj prvky, ktoré efektívne prispievajú $\mathrm{k}$ budovaniu dlhodobého vzt’ahu so zákazníkom (vernostné programy, klubový predaj a pod.).

\section{3 Stratégia osobného predaja}

Osobný predaj kontrastuje s nepriamou komunikáciou. Jeho podstatou je personalizovaná komunikácia, ktorej prostredníctvom sa komerčný oznam dostáva k malej, vel'mi starostlivo vybranej skupine zákazníkov. Osobný predaj sa uskutočňuje prostredníctvom kontaktu medzi predávajúcim a zákazníkom bud' tvárou v tvár alebo prostredníctvom telekomunikačných prostriedkov (Ďad'o, 1992).

Ked’že osobný predaj obsahuje priamu slovnú komunikáciu medzi predávajúcim a potenciálnymi zákazníkmi, zaist’uje tiež priamu spätnú väzbu, ktorá pomáha pracovníkom predaja prispôsobit' sa. Aj ked' pracovníci predaja zohrávajú významnú úlohu v mnohých marketingových mixoch, osobný predaj môže byt' vel'mi drahý, preto je často žiaduce kombinovat' ho s hromadným predajom a jeho propagáciou (McCarthy, 1995). 
Osobný predaj plní viaceré ciele, za najvýznamnejšie sa však považujú: účast' na vytváraní firemného imidžu a vol'ba miesta a techniky predaja, ktoré najlepšie vyhovujú individualite zákazníka (Majtán, 2004).

McCarthy, E. J. (1995) vymedzuje nasledovné tri základné úlohy predaja: získanie zákazníkov, prijímanie objednávok a realizovanie podporných činností. V nadväznosti na uvedené vymedzuje aj úlohy osobného predajcu: „, dobrý pracovník predaja sa snaží zákazníkovi pomôct' pri nákupe tým, že pochopí jeho potreby a bude prezentovat' výhody a nevýhody svojich produktov, pričom výsledkom takejto pomoci môže byt' spokojnost' zákazníka a dlhodobé vzt’ahy; pracovníci predaja reprezentujú celú firmu, ale tiež svojich zákazníkov vo vnútri firmy; pracovníci predaja môžu pomôct' v oblasti informácií o trhu obchodní zástupcovia môžu byt' prvými, ktorí počujú o novej konkurencii alebo o novom výrobku konkurencie či o novej stratégii; pracovníci predaja môžu byt',,plánovačmi“" stratégie - ak dokážu zostavit' ziskové stratégie a správne ich realizovat', majú šancu na rýchly rast a lepšie finančné ohodnotenie“.

\section{4 Stratégia public relations}

Public relations (PR) možno definovat' ako súbor aktivít zameraných na získavanie dôvery verejnosti voči firme, na vytváranie dobrých vzt'ahov k verejnosti prostredníctvom udržiavania priaznivej publicity, budovania „corporate image“, odvracaním nepríjemných a firme škodiacich udalostí (McCarthy, 1995). Podl'a Pospíšila, P. (2002) je činnost' v rámci vzt'ahov s verejnost'ou nepretržitým plánovaným úsilím vedúcim $\mathrm{k}$ dosiahnutiu a udržaniu dobrej vôle a vzájomného porozumenia medzi organizáciou a jej verejnost'ou. „Základným ciel'om PR je transformovat' negatívne pocity verejnosti voči firme na pozitívne pocity, a to nepriatel'stvo na sympatie, zaujatost' na akceptovanie, apatiu na záujem a ignoráciu na poznanie“" (Kita, 1992).

V súvislosti s uvedeným možno vymedzit’ nasledovné úlohy PR (Királ’ová, 1992):

- vytvorit', prípadne posilnit' pozitívny image,

- zaujat', respektíve upevnit' pozíciu firmy na trhu,

- zvýšit' stupeň informovanosti verejnosti o firme,

- motivovat' spolupracovníkov,

- zvýšit' možnost' zamestnat' kvalifikovaných spolupracovníkov,

- snažit' sa získat' pochopenie pre činnost' firmy v očiach verejnosti.

Jedným z najdôležitejších nositel’ov PR vo firme je manažér firmy. Môže sa angažovat' $\mathrm{v}$ súvislosti s rozvojom regiónu alebo mesta, v ktorom firma pôsobí, prácou v profesionálnych združeniach alebo asociáciách. Nositel'mi PR vo firme sú aj spolupracovníci. Každý kontakt so zákazníkom má vplyv na image, dobré alebo zlé meno firmy. Včas poskytnutá služba zodpovedajúcej kvality, úsmev na tvári a priatel'ský tón $\mathrm{v}$ telefóne sú neodmyslitel'nou súčast'ou PR.

Dôležitým predpokladom vytvorenia dobrého mena a image je aj celkový design interiéru a exteriéru firmy. Patrí sem čistá fasáda budovy, kvetinová výzdoba miestností, jednotné oblečenie zamestnancov, využívanie firemného loga, hlavičkového papiera, vizitiek a menoviek v styku so zákazníkmi a podobne.

Firma obvykle využíva nasledovné nástroje PR: tlačové konferencie, briefingy, tlačové komuniké, recepcie, propagačné dni, gastronomické podujatia, dni otvorených dverí, sút’aže, suportové podujatia, direkt mail, konferencie a semináre, vel'trhy a výstavy, verejné vystúpenia predstavitel'ov firmy $\mathrm{v}$ médiách, sponzoring, charitatívnu činnost' a podobne (Vávra, 1998). Súčast'ou PR je aj príprava písomných podkladov a vydávanie interných periodík. Sem patria ročné správy, brožúry, články, firemné noviny a časopisy, audiovizuálne materiály. Firemný znak, symboly, vizitky, objekty firmy, uniformy, firemné osobné a nákladné autá - to všetko môže byt' prostriedkom komunikácie prispievajúcej k tvorbe image 
firmy (Kotler, 1992). Podl'a Pospíšila, P. (2002) PR zahŕňa nasledovné činnosti: stanovenie komunikačnej politiky, sponzorstvo, firemnú identitu, interné a externé materiály, platenú reklamu, priamu komunikáciu s verejnost'ou, investormi a vládou, organizovanie akcií, publicitu, vzt'ahy s médiami (media relations) a spin doctoring (využitie dobrého publicistu, ktorý obhajuje záujmy firmy a dostáva ich do zorného uhla médií). Podl’a Kotlera, P. (2003) možno v rámci PR využit' množstvo nástrojov s ciel'om upútat' pozornost' a vytvorit' pozitívnu atmosféru, aby sa o výrobkoch ,začalo hovorit“". Súbor týchto nástrojov autor prezentuje na modeli PENCILS: publikácia (Publications), udalosti (Events), správy (News), zapojenie sa do miestnej komunity (Community affairs), identifikačné médiá (Identity media), lobovanie (Lobbing) a služby verejnosti (Social investments).

Kým podpora predaja zahŕňa skôr krátkodobé aktivity, podstatou PR sú dlhodobé ciele ako tvorba dobrého mena (goodwill) a predstavy (image), posilnenie pozície firmy a značky (loga) na trhu.

\section{5 Stratégie špecifických prvkov marketingovej komunikácie}

V rámci stratégií špecifických prvkov marketingovej komunikácie možno hovorit' o stratégii priameho (direct) marketingu, ktorý bol na zač. 60 . rokov chápaný ako určitý typ distribúcie (priamy predaj prostredníctvom rôznych kanálov), pretože bol najviac využívaný vo forme zásielkového predaja. V 70. rokoch sa stal nástrojom marketingovej komunikácie s dôrazom na spätnú väzbu a optimalizáciu reakcií na „mailing“ a d'alšie priame marketingové nástroje. V 90. rokoch sa hlavnými znakmi priameho marketingu stalo budovanie dlhodobých vzt’ahov a zvyšovanie lojality zákazníkov.

Hoci sa to zdá nelogické, aj priamy marketing využíva masové, resp. neadresné médiá, ale rozdiel od bežnej masovej komunikácie spočíva $v$ tom, že sa generuje priama reakcia príjemcov oznamu. Dôležitou čast'ou reklamných aktivít je reklama s priamou reakciou (tlačené reklamy umožňujúce odpoved', televízne a rozhlasové reklamy). Medzi médiá a nástroje priameho marketingu tak možno zaradit': interaktívnu televíziu (DRTV - direct response television - médium, ktoré generuje reakciu, telefonickú odpoved'), teletext, priame zásielky (direct mail), telemarketing, katalógy, využívanie nových interaktívnych médií (CDI, CD-ROM, Internet, interaktívny teletext, webové stránky a e-mail) (Pelsmacker, 2003).

Stratégia komunikácie v mieste predaja (POP - Point of Purchase, resp. POS - Point of Sale) predstavuje vel'mi významný nástroj, pretože pôsobí na zákazníka v momente rozhodovania o nákupe produktu alebo značky. Ciel'om tejto komunikácie je pritiahnut' pozornost' zákazníka, poskytnút' mu informácie a presvedčit' ho. V rámci POP komunikácie je potrebné sa zaoberat' nasledovnými aspektmi: imidžom obchodu (predajne), jeho organizáciou a usporiadaním, prezentáciou tovaru, atmosférou predajne, balením a obalom produktu (Pelsmacker, 2003).

Stratégia komunikácie prostredníctvom výstav a vel'trhov predstavuje podobne ako priamy marketing a osobný predaj viac osobný komunikačný nástroj. Ciel'om účasti firmy na výstave či vel'trhu môže byt': predaj tovaru, zavedenie alebo testovanie nového produktu, posilnenie povedomia o značke a firme, predvádzanie výrobkov a služieb, podpora imidžu firmy, posilnenie internacionálnej úrovne povedomia o svojich značkách, zoznámenia sa s novými produktmi a politikou konkurentov, nábor nových predajcov alebo dílerov a pod. Smith, P. (2000) uvádza, že ciel'om účasti na výstave môže okrem uvedeného byt' snaha: udržat' si pozíciu na trhu, využit' interné (obežníky) a externé možnosti vzt'ahov s verejnost'ou prostredníctvom správ v tlači; posilnenie vzt’ahov so zákazníkmi, distribútormi a agentmi prostredníctvom pohostinnosti a predstavením vrcholových manažérov firmy; podpora lokálnych distribútorov a agentov - samotnou exhibíciou, testovanie nových nápadov, analýza konkurencie a koncentrácie informácií, motivácia personálu. 
Výstavy možno podl'a Pelsmackera, D. P. (2003) rozdelit' na verejné výstavy (všeobecne zamerané, špecificky zamerané) a na obchodné výstavy (horizontálne, vertikálne, spojené s konferenciou, obchodné trhy).

Stratégia komunikácie prostredníctvom multimédií prestavuje komunikáciu prostredníctvom napr. videa, fotografie, zvuku atd'., ktoré sú spojené kreatívnym a interaktívnym spôsobom. Multimédiá môžu byt' doručované na disku (DVD, CD-ROM) alebo online, na počítači napojenom na Internet (Smith, 2000).

Stratégia internetovej komunikácie je založená na využívaní nového interaktívneho média - Internetu, ktorý sa od tradičných komunikačných médií líši: komunikačným štýlom (je takmer synchrónny, doba medzi odoslaním a prijatím informácie je zanedbatel'ná), možnost'ou kontroly kontaktu (cesty a prezentácie informácií) zákazníkom, možnost'ou kontroly obsahu zákazníkom (výber informácií) a spoločenským aspektom (ozvučenie a video robí webové stránky viac spoločenské). Podl'a Pelsmackera, D. P. (2003) možno prostredníctvom uvedenej stratégie dosiahnut' nasledovné komunikačné ciele: ovplyvnit' prístup a budovat' povedomie o značke a produkte, poskytnút' obsah (detailné informácie o výrobkoch a službách), stimulovat' odpoved', ul'ahčovat' transakcie (on-line predaj) a udržiavat' si zákazníkov.

\section{Marketingové komunikačné stratégie diferencované podl'a spôsobu vytvárania dopytu}

Ak základným ciel'om komunikácie bude snaha vytvorit' na trhu dopyt po produkcii firmy, čo sa následne prejaví vo zvýšení jej odbytu a zvýšení ziskov z predaja, firma bude realizovat' pravdepodobne niektorú z nasledovných komunikačných stratégií (Foret, 2003):

1. stratégiu tlaku (push-strategie) - firma sa snaží produkt pretlačit' cez distribučné kanály k zákazníkovi, pričom z pohl'adu komunikácie využíva predovšetkým osobný predaj a podporu predaja. Producent presvedčí predajcu o výhodnosti svojho produktu a ten následne $\mathrm{v}$ tomto zmysle pôsobí d’alej na zákazníkov. Uvedenú stratégiu v praxi využívajú najmä vel'ké, kapitálovo silné a nadnárodné firmy.

2. stratégia t’ahu (pull-strategie) - firma sa snaží najskôr vzbudit' záujem zákazníkov, vyvolat' dopyt po prítažlivom produkte, využíva pritom najmä reklamu a publicitu v rôznych komunikačných prostriedkoch, ktoré vyvolávajú následný záujem u zákazníkov, títo sa potom informujú ohl’adom daného produktu u maloobchodníkov. Maloobchodníci prenášajú požiadavky zákazníkov $\mathrm{k}$ vel'koobchodníkom, či dokonca priamo $\mathrm{k}$ výrobcom. V prípade tejto stratégie má producent prít’ažlivý produkt, ktorý pri svojej prezentácii dokáže okamžite sám osebe zaujat' zákazníkov. V praxi sa daná stratégia objavuje skôr u malých, začínajúcich a na podnety vnímavých firiem.

Obidve stratégie vychádzajú predovšetkým z nátlaku. V prvom prípade tlačí výrobca na predajcu a ten na zákazníka. V druhom prípade je smer tlaku obrátený - zákazník tlačí na predajcu a ten na výrobcu. $Z$ toho vyplýva, že obidve zo stratégií môžu využívat' rovnaké propagačné nástroje, ale $\mathrm{v}$ inom kontexte. (napr. reklama $\mathrm{v}$ mieste predaja je typická skôr pre stratégiu tlaku, zatial' čo reklama v masovokomunikačných prostriedkoch je vhodná skôr pre stratégiu t'ahu; v praxi sa však v konečnom dôsledku obidve použité reklamy navzájom kombinujú a dopíňajú). V obidvoch stratégiách hrá rozhodujúcu úlohu distribúcia. V prípade stratégie tlaku musí najrôznejšími kombináciami propagačných nástrojov zabezpečit' maximálny predaj produktu, naopak v prípade stratégie t’ahu distribúcia vyhl'adáva a presviedča výrobcu, aby prednostne dodávali produkty, po ktorých je dopyt.

Je potrebné zdôraznit', že obidve uvedené stratégie sú vyhrotenými krajnými variantmi, osobne si myslím, že sa v praxi často prelínajú a kombinujú, teda nás skôr zaujíma, ktorá stratégia v konkrétnom prípade a okamihu prevažuje. 


\section{Marketingové komunikačné stratégie diferencované podl’a ciel'ov komunikácie}

Firma môže realizovat' rozličné komunikačné stratégie diferencované v závislosti od ciel'ov, ktoré chce prostredníctvom marketingovej komunikácie dosiahnut'. Vychádzajúc zo základných ciel’ov komunikácie možno následne rozlíšit': stratégiu informovania o nových produktoch (napr. o nových kozmetických prostriedkoch, ktoré sa vyznačujú vyššou kvalitou, účinnost'ou a pod.), stratégiu presviedčania o výhodách (prednostiach) ponúkaných produktov (napr. výhody nového pracieho prostriedku v porovnaní s „tradičným“), stratégiu pripomínania, ktorá je dôležitá najmä z hl'adiska životného cyklu produktu (napr. reklama typu: „Deli sa vracia!“).

\section{Marketingové komunikačné stratégie diferencované podl'a objektu ich zamerania sa}

Firma realizuje svoju komunikačnú stratégiu predovšetkým smerom k zákazníkom a potenciálnym zákazníkom. V tvrdom konkurenčnom prostredí by bol však takýto prístup nedostatočný, a preto úsilím každej firmy či organizácie je prostredníctvom komunikácie ovplyvnit' aj iné skupiny. Tak môžeme hovorit' o komunikačných stratégiách zameraných do oblasti budovania vzt'ahov s verejnost'ou, ktorú okrem zákazníkov tvoria: investori, konkurenčné firmy, vlastní zamestnanci firmy a budúci zamestnanci, záujmové a vplyvové skupiny, nátlakové skupiny, orgány štátnej správy a samosprávy a d’alší.

\subsection{Stratégia interného public relations}

Jedno zo starých známych pravidiel PR tvrdí, že „public relations začína doma“. Použitie výrazu interné PR naznačuje, že ide o disciplínu, ktorá úzko súvisí s personálnym oddelením, ale aj s inými organizačnými čast’ami firmy. Tým, že sa kladie taký dôraz na interné $\mathrm{PR}$, reflektuje sa stúpajúca potreba zamestnancov mat' prístup $\mathrm{k}$ dôležitým informáciám a podiel'at' sa na rozhodovaní. Stále platí, že zamestnanec je „chodiacou reklamou“ vlastnej firmy, znalcom zákazníkov a ich potrieb, nevyčerpatel'nou studnicou inšpirácie, ale musí byt' aj prvým konzumentom a kritikom všetkých komunikačných aktivít svojej firmy.

Interné PR má potom za úlohu predovšetkým (Belovický, 1999):

1. uspokojit' zvedavost' zamestnancov s ohl'adom na chod podniku,

2. sprehl'adnit' komplikované organizačné štruktúry vo vel'kých podnikoch,

3. vyvolat' u zamestnancov potrebu podiel'at' sa na rozvoji firmy,

4. získat' od zamestnancov spätnú väzbu pri príprave komunikačných kampaní,

5. vyvolat' pozitívny obraz organizácie $\mathrm{v}$ očiach zamestnancov, ich rodinných príslušníkov, a s tým spojenú lojalitu k organizácii vrátane zníženia fluktuácie.

Všetky hore uvedené úlohy a zároveň možnosti využitia celej škály internej PR komunikácie by si mali dobre uvedomit' predovšetkým riadiaci pracovníci. Vybudovanie dobrého tímu, efektívnej práce, motivačných systémov, hrdosti k firme a vzájomnej zastupitel’nosti je často pre mnohých vedúcich pracovníkov takmer neriešitel'nou úlohou. Preto zastávam názor, že dobrý manažér by prácu s l'ud'mi nemal nikdy podceňovat'.

\subsection{Stratégia sponzoringu}

Vel'mi flexibilný komunikačný nástroj, ktorý môže byt' využitý ako pre marketing (produkt a značku), tak aj pre komunikačné ciele firmy, sa označuje pojmom sponzoring.

„Sponzoring môžeme definovat' ako investovanie peňazí alebo iných vkladov do aktivít, ktoré otvárajú prístup ku komerčne využitel'nému potenciálu, spojenému s danou aktivitou. Firmy podporujú svoje záujmy a značky tým, že ich spájajú s určitými významnými 
udalost’ami alebo aktivitami. Sponzoring je nástroj komunikácie, kedy sponzor pomáha sponzorovanému uskutočnit' jeho projekt a sponzorovaný pomáha sponzorovi naplnit' jeho komunikačné ciele. Ak sa tak nestane, sponzorstvo sa stáva len obyčajným darcovstvom“ (Pelsmacker, 2003). Foret, M. (2003) pod sponzoringom rozumie: „cielené financovanie „ostatných“" subjektov (nezárobkových) za účelom vytvorenia dobrej povesti danej firmy“.

Z väčšiny štúdií vyplýva, že najdôležitejším komunikačným ciel’om sponzoringu je podpora imidžu firmy a dobrého mena u rôznych ciel'ových skupín.

V rámci stratégie sponzoringu môže firma realizovat': sponzorstvo udalostí (napr. športových, kultúrnych, politických), sponzorstvo vysielaní alebo programov (tento typ je najbližší reklame, pretože pokial' ide o povedomie a imidž, môže naplnit' podobné ciele), účelové sponzorstvo (MUSH - jedná sa o kombináciu PR, podpory predaja a firemnej filantropie, kedy sa peniaze vynaložia na dobrú vec a očakáva sa pozitívny vplyv na imidž značky), ambush marketing - sponzorstvo zo zálohy (závetria) (firma vedome hl'adá spojenie s určitou udalost'ou, bez toho, aby platila sponzorský poplatok, aby presvedčila publikum, že je legitímnym a hlavným sponzorom, napr. nadsadením zapojenia organizácie do udalosti reklamou či podporou predaja $\mathrm{v}$ priebehu udalosti), sponzorstvo transakcií (nazývané aj účelovo zameraný marketing alebo politika nákupného bodu - firma investuje určitú čast' peňazí na dobrý účel vždy, ked' spotrebitel' kúpi produkt. Sponzorstvo je teda jedným $\mathrm{z}$ aspektov hodnotového alebo spoločenského marketingu) (Pelsmacker, 2003).

Foret, M. (2003) uvádza, že v praxi môže firma realizovat': stratégiu exkluzívneho sponzoringu (sponzor preberá všetky navrhnuté výkony), stratégiu hlavného sponzoringu (sponzor preberá najdrahšie a najatraktívnejšie protivýkony) a napokon stratégiu kooperačného sponzoringu (protivýkony sú rozdelené na vel'ký počet rôznych firiem).

\section{Záver}

Stratégia propagačného mixu, ktorú si firma vyberie pre komunikáciu s určitým segmentom trhu závisí predovšetkým od povahy produktu a štádia jeho životného cyklu, ciel'a propagácie, identifikácie ciel’ového trhu, na ktorý má byt' komunikácia nasmerovaná, charakteru konkurencie a rozpočtu na propagáciu. Je potrebné zdôraznit', že za dôležitú súčast' propagačnej činnosti je potrebné považovat' aj samotných pracovníkov predaja, ktorí úzko spolupracujú so sprostredkovatel'mi nielen preto, aby získali objednávky, ale tiež aby vysvetl'ovali marketingový mix svojej firmy a nadviazali spoluprácu s jednotlivými predajňami a koordinovali tak úsilie medzi jednotlivými článkami distribučnej cesty. Hlavnou úlohou marketingového manažéra v oblasti propagácie je informovat' ciel’ových zákazníkov o tom, že správny produkt možno získat' (kúpit') na správnom mieste a za správnu cenu. Aké informácie marketingový manažér poskytuje závisí od potrieb a názorov cielových trhov. Ako sú tieto správy podávané, záleží na tom, aké spojenie rôznych metód propagácie marketingový manažér vyberie (McCarthy, 1995).

Dlhodobá stratégia firmy je založená na tvorbe a posilňovaní obrazu značky na verejnosti, posilňovaní vernosti užívatel'a i na tom, že firma získava nových užívatel'ov. Obraz spoločnosti na verejnosti je stredobodom akejkol'vek strategickej dlhodobej komunikácie firmy (Smith, 2000).

\section{Literatúra}

1. BELOVICKÝ, D.: Interné public ralations. Marketing magazine, č. 7-8/1999, ISSN 12117315

2. BOVÉE, C. L. - THILL, J. V.: Marketing. USA: McGraw-Hill, 1992, ISBN 0-07006734-1 
3. BRADBURY, A.: Jak úspěšně prezentovat a přesvědčit'. Praha: Computer Press, 2003, ISBN 80-7226-424-9

4. CLEMENTE, N. M.: Slovník marketingu. Brno: Computer Press, 2004, ISBN 80-2510228-9

5. ČIHOVSKÁ, V. - KITA, J.: Nové paradigmy marketingu v procese globalizácie trhov. Ekonomický časopis. č. 6/2005, ISSN 0013-3035

6. ĎAĎO, J. - KIRÁLOOVÁ, A. - LESÁKOVÁ, L.: Marketing v drobnom podnikaní. Bratislava: EU Bratislava, 1992, ISBN 80-225-0420-3

7. FORET, M.: Marketingová komunikace. Brno: Computer Press, 2003, ISBN 80-7226$811-2$

8. FOSTER, T.: Jak získat a udržet zákazníka. Praha: Computer Press, 2002, ISBN 80-7226$663-2$

9. HINGSTON, P.: Efektívny marketing. Bratislava: IKAR, 2002, ISBN 80- 551- 0399-2

10. HORÁKOVÁ, I.: Marketing v současné světové praxi. Praha: Grada Publishing, ISBN 80-85424-83-5

11. HORŇÁK, P.: Abeceda reklamy. Bratislava: Grafosit s. r. o, 1997, ISBN 80-967701-79659.1

12. HURST, B.: Encyklopedie komunikačních technik. Praha: Grada Publishing, 1994, ISBN 80-85424-40-1

13. IŽARIK, Š. - FRIANOVÁ, V. a kol.: Základy marketingu. Liptovský Mikuláš: Vojenská akadémia, 2000, ISBN 80-8040-146-2

14. KOTLER, P.: Marketing od A do Z. Praha: Management Press, 2003, ISBN 80-7261-0821

15. KOTLER, P.: Marketing podle Kotlera. Praha: Management Press, 2004, ISBN 80-7261010-4

16. LESÁKOVÁ, D.: Nové trendy v marketingu tretieho tisícročia. Ekonomický časopis, č. 6/2001, ISSN 0013-3035

17. MAJTÁN, Š. a kol.: Odbytová stratégia. Bratislava: Ekonóm, 1999, ISBN 80-225-1082-3

18. MCCARTHY, J. E. - PERREAULT, W. D.: Basic marketing. Boston: IRWIN, 1990, ISBN 0-256-06865-8

19. PELSMACKER, P. - GEUENS, M. - BERGH, J.: Marketingová komunikace. Praha: Grada Publishing, 2003, ISBN 80-247-0254-1

20. POSPÍŠIL, P.: Efektivní public relations a media relations. Praha: Computer Press, 2002, ISBN 80-7226-823-6

21. SMITH, P.: Moderní marketing. Praha: Computer Press, 2000, ISBN 80-7226-252-1

22. ŠÍBL, D.: Vel'ká ekonomická encyklopédia. Bratislava: Sprint, 2002, ISBN 80-89085-040

23. ŽÁRY, I.: Public relations - komunikačná disciplína. Otázky žurnalistiky, č. 1-2/2001, ISSN 0322-7049 